\title{
Mapping the History of Sociology: Places, Positioning, Dominance and Marginality in an Emerging Discipline*
}

\author{
CHRISTOPH REINPRECHT 1 - NORA WALCH ${ }^{2}-$ \\ JIŘÍ ŠUBRT 3
}

Mapování dějin sociologie: Místa, pozice, dominance a marginalita v objevené disciplině

\begin{abstract}
The paper is a contribution to a sociological reading of a decisive moment in the history of Austrian and Viennese sociology: the early 20th century. In this early period of its establishment, the Austrian (and especially Viennese) sociology is known for its intellectual vitality, the diversity of its competing circles, its methodological innovations. At the same time, sociology appeared as a highly fragmented scientific field with dominant strands, today on the fringes of the discipline, and with peripheral and marginalized trends and positions, appreciated today as pioneers of modern sociology. By applying a topographic approach, the paper elaborates specific characteristics of this field, including the different degree of institutionalization in and outside the Universities, in connection with political and ideological struggles for discursive hegemony, or the deep gap between theoretical and empirical approaches, related to the effects of multidimensional and intersectional marginalization on protagonists of the sociological field who are today recognized as important innovators. With its focus on the material dimension of knowledge production and its particular attention to places and the localization of actors, methods, and thoughts, and the related (unequal) positions in the social field of science, the paper aims to contribute to a critical understanding of processes of marginalization as a constitutive, and driving, element in science history.
\end{abstract}

Keywords: history of sociology; sociology in Austria; Vienna; empirical sociology; marginalization; social field of science; position, place; localization; network

DOI: $10.14712 / 23363525.2019 .2$

\section{Introduction}

The history of Austrian sociology - as well as the history of sociology in other countries can be traced and shown from different perspectives, with varying degrees of detail [see e.g. Dayé - Moebius 2015]. Examples for approaches trying to narrate the history of the discipline are, amongst others, the attempts "to show how things actually happened" (Leopold

* This article was created with support of Operation Programme Research, Development and Education, project "International Mobility of Charles University Research Workers," registration number CZ.02.2.69/0.0/0.0/16_ 027/0008495.

1 Prof. Dr. Christoph Reinprecht, Department of Sociology, Faculty of Social Sciences, University of Vienna, Rooselveltplatz 2, A-1090 Wien. E-mail: christoph.reinprecht@univie.ac.at.

2 Nora Walch, Department of Sociology, Faculty of Social Sciences, University of Vienna, Rooselveltplatz 2, A-1090 Wien. E-mail: nora.walch@univie.ac.at.

3 Doc. PhDr. Jiří Šubrt, CSc., Department of Historical Sociology, Faculty of Humanities, Charles University, U Kř́žze 8, 15800 Praha 5. E-mail: Jiri.Subrt@fhs.cuni.cz. 
von Ranke), the compartmentalization of intellectual practices into distinct phases and lines of development, the assignation and analysis of "cultures of knowledge," approaches of history of idea, socio-historical/socio-genetical contextualizations, perspectives of professionalization and institutionalization, systematization and the creation of types, case studies, (auto-/collective-) biographical depictions/narrations.

Each of these approaches comes with certain fields of interest and can have various focuses. Some are oriented towards institutional realities/evidences (e.g. habilitations, institute foundations), towards persons, careers or biographies, others focus on written documents (un-/published papers etc.), or on modes of interaction and communication (letter exchanges, formation of intellectual "circles"), some are interested in scientific immanent criteria of disciplinary, conceptual and methodological differentiation or in the political and social circumstances underlying a certain scientific situation (politics, status of universities etc.). All of these approaches show and represent specific aspects and details and reflect certain epistemological positions, creating visibility and invisibility. However, they all share the consensus about the circumstances in which sociology constituted itself: In Austria, the scientific field of sociology experienced rapid and broad-based prosperity. Characteristic of this time was not only very frequent self-organization (taking the form of clubs, discussion circles, and study groups), but also efforts to shape, practice and promote new attitudes to theory and research methods, while being exposed to an anti-modernist and an anti-sociological posture of a considerable part of the bourgeois elite hindering the establishing and institutionalization of sociology. Within the scientific field, disciplinary self-understandings and scientific practices differed strongly, often based on ideological and political agendas, and impacted by crucial historical changes and events $(1918,1933$, 1938). Another important aspect was the private and exclusive character of intellectual life and the formation of circles and groups often taking place in semi-public or even private settings. Innovative methods and approaches, many of them already developed in the interwar period, found resonance and scientific recognition in the academic field primarily outside of Austria, in many cases only in the context of forced exile.

Despite their diversity, most contributions to the history of Austrian sociology operate with predominant variables and schemes referring to protagonists including the relationship between intellectual mentors and their disciples, or to processes of institutionalization and the resources and privileges scientific and academic institutions provide, or to ideas, texts, terminologies, discourses and the intellectual milieus and "schools" they emerge from by applying hierarchical concepts such as insiders and outsiders, center and periphery and by connecting this narrative to crucial (external) historical events.

The emphasis on these dominant variables blurs the fact that "Austrian sociology" represents a social field in which the relations between the mentioned variables (institutions, protagonists, ideas, texts, resources, and privileges) are always connected to the fabric and the material situations of relevant places of sociological knowledge production and imaginary: University and research centers (such as the Wirtschaftspsychologische Forschungsstelle/ Research Center for Economic Psychology) constitute material, physical structures, anchored in the city and urban environment, in which, at the same time, local conditions of production manifest themselves. Scientific and academic institutions are not only representing discursive spaces, equipped with cultural and symbolic capital, but also various typical modes of sociological production of knowledge: Constellations of social 
situations and practices, of individual and collective actors, of ideas and material elements overcoming and leaving behind the narrow frame of a seemingly homogeneous, coherent, and self-contained unit.

This leads us to use of the terms place and localization. The concept of the place highlights materiality and refers to a position in the urban fabric generating certain conditions of scientific knowledge production. That means that the production of knowledge can always be localized, and it is positioned, often in multiple ways. In this understanding, places as positions are relational, part of a social field constituted of relationships. The positioning within this field primarily defines interests and epistemological perspectives, besides facilitating social status and power. The term place also refers to cross-linked networks, flows of ideas and concepts, text production, reception, discourses, scientific biographies, and encounters. The term localization enables us to make the social field and its functioning visible, e.g. the intersectional mode of marginalization which played a constitutive role in the emergence of modern empirical sociology in Austria. The term localization also emphasizes the importance of the perspectives and standpoints of the actors (and observers) involved. Places are assigned with certain attributes and meanings and connected with each other in many ways.

Our topographical approach - in the sense just carried out - is certainly not limited by placing certain pins on a geographical map. As we will demonstrate in our article, this approach rather enables us to develop the argument that marginalization has been constitutive for the Viennese sociology which today is perceived as mainstream and most influential and recognized internationally. This empirically oriented sociology was developed at the margins, and outside of academic institutions, often forced into isolation, also in terms of spatial distanciaton, and its representatives in vivant interactions with each other but also with places, positions and actors also from outside its own field, elaborating and negotiating the order of the discipline, objects of research interests, and methodological principles and practices.

From this perspective, employing the term "Austrian sociology" would be simplifying, as we rather want to conceptualize this history as a network of circles and lines, ways of thinking (styles of thought) and intellectual strands which overlap or entangle but also fight each other, or self-contain themselves. After a brief introduction of the historical landscape of the Austrian sociology at the beginning of the 20th century, with a special focus on Vienna, the article develops the topographic approach against a critique of predominant ways of telling the history of the discipline and in drawing a picture of the sociological field by paying attention to its places and locations. A specific focus lies on the flourishing of empirical sociology and its marginal positioning, elaborating four typical contexts.

\section{Historiographic legacies of narrating Austrian sociology}

A traditional way of telling the history of Austrian sociology, as we can find it in many textbooks and manuals, is focusing on key personalities and intellectual currents. It is a narrative reconstruction of the formation and development of a discipline rather than a sociologically informed reading of the constitution of a social field in the sense of a "sociology of sociology" [Bourdieu 1993; Fleck 1999; Fleck 2015]. A narrative structure is 
commonly requiring a starting point, in the case of Austria this could be the establishment of a chair for cameralism at the Faculty of Law in Vienna in 1763, reflecting the need of the "enlightened absolutism" to develop a comprehensive understanding of the relation between state and economy [Norden et al. 2015]. At that time, and similar to Auguste Comte or Herbert Spencer, "society" was conceived on the analogy of the functioning of the organism. The role of the social sciences is defined to understand, and to improve, the modus operandi of the state and public administration in terms of social stability and order. This approach was especially true for Lorenz von Stein (1815-1890) who held for thirty years a professorship for political economy at the University of Vienna, ${ }^{4}$ as well as for most of his successors such as Albert Schäffle (1831-1903), known for his four-part treatise Construction and Life of the Social Body [Schäffle 1875-1887], or Othmar Spann (1878-1950) who continued to advocate a theoretical understanding of sociology as science of society (Gesellschaftslehre). Spann held the professorship since 1920. He followed Eugen von Philippovich (1858-1917), a more empirically oriented "academic socialist" who was interested in studying the living and housing conditions of working-class people [Philippovich 1894]. Max Weber (1864-1920) had refused the offer to assign the professorship.

Attempts to draw a coherent picture of early Austrian sociology often fail due to its polyphonic and fragmented character. The mentioned holistic- and organizational strand which dominated particularly the Viennese academic field for decades, and which had in the 1920s and 1930s in Othmar Spann a militant leader and ideologist, developed in interaction with the Catholic social doctrine, deeply anchored in former Habsburg intellectual life which impacted the milieu of conservative social scientists - from left-wing Ernst Karl Winter (1895-1959) to far right-wing intellectuals such as August Maria Knoll (1900-1963) or Eric Voegelin (1901-1985), also after 1945. In epistemological and ideological contrast to it, the many social scientists influenced by Marxist thoughts constituted also a rather inhomogeneous group of people, and in more or less affinity to the Austromarxist movement and politics. Beside these bigger strands, there were disciples of moral statistics which had a relatively long-lasting influence on the further development of sociological thinking in Austria. One of its representatives, Tomáš G. Masaryk (1850-1937), authored a sociological work on suicidal tendencies ("Suicide as a Social Mass Phenomenon of Modern Civilization" [Masaryk 1881]) and became first Czechoslovak president in 1918. Other people are recognized due to their founding role, such as Rudolf Goldscheid (1870-1931), the initiator of the Sociological Association in Vienna; their scientific innovations - Jacob L. Moreno (1889-1974), the founder of sociometry; or their writings Alfred Schütz (1899-1959). This polyphonic picture is becoming even more complex if the interrelations with other fields of science are taken into consideration, be it the "pure theory of law" - Hans Kelsen (1881-1973); the "Austrian school of economic thought" Carl Menger (1840-1921), Friedrich Hayek (1899-1992); logical empiricism - Ernst Mach (1838-1916), and Vienna Circle; or psychoanalysis - Sigmund Freud (1856-1939). An often applied method to organize this complex picture is the concept of scientific or intellectual circles, allowing to integrate the diverse elements of this field into a coherent narrative structure [Müller 1988].

4 Stein delt with state-science [Stein 1856]. 
In his instructive study “The Origin of Sociology in Austria 1885-1935," John Torrance [1976] interprets the early phase of Austrian sociology in the light of the political and ideological polarization, and the "anti-modernist" and "anti-sociological" posture of huge parts of the national bourgeoisie; both phenomena were significant elements of the societal environment in which sociology emerged. According to Torrance, Austrian sociology has developed remarkable innovations which, however, mostly became established only much later and outside Austria, mostly in the context of exile. Some innovations refer to the writings of authors rooted in and inspired by the social reality (in particular the nationality conflicts) in the edge of the old empire: Ludwig Gumplowicz' (1938-1909) (political) sociology of ethnic relations [Gumplowicz 1883], Gustav Ratzenhofer's (1842-1904) sociology of interest group conflicts [Ratzenhofer 1907], and Ehrlich's sociology of law (1913). Gumplowicz and Ehrlich, born in Galicia or Bukovina, shared as Jews the experience of strong antisemitism in and outside the University. The writing of these sociologists received much attention, especially in the United States.

Another innovative strand refers to the Austro-Marxist sociology which had in Max Adler (1873-1937) an outstanding academic representative. Adler completed his habilitation in sociology in 1919, supported by Hans Kelsen and against the resistance of the reactionary-conservative Catholicism circle around Othmar Spann; but he never achieved a recognized position in the academic field. In the interwar period, Vienna was a left-wing governed city where Austromarxists tried to establish a political and cultural counter-balance to the dominant reactionary Catholicism on national levels; this project finally failed in reaching hegemony [Negt 1972]. The specific character of Austromarxist sociology lied in the attempt to combine Marx with Kant and the "good" ideals of the bourgeoisie, e.g. in the field of culture and education; at the same time, due to its rationalistic orientation, it was open for (quantitative-positivist) empirical research. Austromarxism is associated with famous names such as Otto Bauer (1881-1838), Karl Renner (1870-1950), Rudolf Hilferding (1877-1941), or Otto Neurath (1882-1945), the inventor of the Viennese method of pictorial statistics. Other people held a place more at the margins such as the economist Joseph Schumpeter or the academic psychologists Karl Bühler (1879-1963) and Charlotte Bühler (1893-1974), but who significantly inspired the Vienna School of Empirical Social Research with Käthe Leichter (1895-1942), Marie Jahoda (1907-2001) or Paul F. Lazarsfeld (1901-1976) as most known representatives.

Many innovations are related to the dense interlinkages with above-mentioned streams outside sociology - namely modern psychology and psychoanalysis on the one hand, pure law theory and logical empiricism on the other - which later came to world renown: the research centre for economic psychology (Wirtschaftspsychologische Forschungsstelle) founded by Paul F. Lazarsfeld, and responsible for conducting the famous Marienthal study; the research group on authoritarian character, organized by the Frankfurt Institute for Social Research in which, among others, Käthe Leichter, Marie Jahoda and Else Frenkel-Brunswik (1908-1958) participated; the alternative pedagogy of a Siegfried Bernfeld (1892-1953).

Highlighting the conceptual and methodological innovations underlines the gap between the locally anchored strands, of provincial character and under the influence of political Catholicism, based on antisemitism and antifeminism, and also behind the international trends and developments in social sciences on the one hand, and the inter- and 
transnationally in multiple ways oriented and embedded modern (and often empirical) sociology on the other hand. Following Fleck [1990], the institutionalization of the discipline in the academic field was massively hindered by the above-described conditions in the pre- and interwar time. With respect to the criteria of sociology as an academic profession and discipline, Austrian sociology only became established during and after the Second World War in the context of forced emigration and exile. Marie Jahoda and Paul F. Lazarsfeld are emblematic for this fact and experience.

\section{Places, networks, and positions in Austrian sociology}

In his research, Fleck convincingly shows the impending impact of the societal circumstances on the institutionalization of sociology as a professional discipline; however, his specific and narrow understanding of scientific discipline (and professionalization) leads to the reproduction of the dominant linear historical narrative and a conventional understanding of science and academic discipline. One of Fleck's references to a "sociological history of sociology" [Fleck 1999] comes from E. Shils [1970] who states that sociology can be defined as a discipline in which: (a) there is a large group of people who are in a certain structured relationship to each other and to each other as sociologists; (b) practices are built on disciplinary traditions and are related to the transfer of knowledge on the principle of relations between mentors and disciples within the scientific community; (c) funding for sociological research is provided. This perspective allows a system-bounded analysis of sociology as an academic field (habilitations, chairs, scientific publications, quotations, funded research), and within the logic of this approach, Fleck convincingly argues the provincial character of the sociology established in Austria's academic institutions, whereas the "other sociology" with its significant scientific potential rapidly found resonance within the international academic community. However, in his contributions, he systematically leaves aside some specific components of the emerging sociological field, in particular all the material components, places, and positions highly relevant for the discipline but not academically affiliated or not explicitly classifiable or translatable into criteria of scientific institutions. This particularly also refers to structural characteristics of people involved: women, many of them of Jewish origin, with Marxist background, but also liberal intellectuals and political and humanitarian activists ("intersectional marginalization"), and their methods and concepts as well as the places constitutive for the field of empirical social sciences (research units, publishing houses, places of research etc.).

Our argument is that marginalization - as a constitutive element of Viennese sociology - cannot be sufficiently depicted without considering its spatial dimension. Sociology, especially as an empirical science, is more than just an intellectual relation as it always unfolds in concrete physical contexts and places, relevant for the production of knowledge, for the development and application of research methods, for the circulation and transmission of knowledge, and for the realization of social concepts through interventions in society. Places also serve as crystallization points for structural parameters. In research on the history of Austrian and Viennese sociology, the concept of intellectual circles is often used to describe this social form of intellectual grouping as an opportunity structure. This method also represents a kind of mapping, for which concrete places (sites) may play a constitutive role. This focus on lieux de savior [Jacob 2007] is certainly appropriate for the 
diverse and fragmented landscape of social sciences in Vienna. Interestingly, the environment of these circles are named - University departments, coffee houses, private settings etc. - without considering the physical structure, equipment, and position of these places, and their interrelation, as relevant constituents for the scientific production.

As part of ongoing research on constitutive places for the field of sociology in Vienna, we focus on the anchoring of sociological thinking and research in urban space. In our understanding, places of sociology are those where scientific interests and research agendas are encountering the phenomena of the modern city. It can be assumed that in these places, which are in fact physical facilities, certain socio-political and scientific-theoretical positions and conflicting lines crystallized.

\section{The field of Viennese socio-scientific thinking}

As already stated, sociology in Austria - particularly in Vienna - at the end of the 19th century and in the early decades of the 20th century, experienced rapid and broad-based prosperity. Characteristic of this time was not only very frequent self-organization (taking the form of clubs, discussion circles, and study groups), but also efforts to shape, practice and promote new attitudes to theory and research methods. Along with this, however, there was still insufficient academic recognition and establishment on the premises of universities. This was particularly the case of the empirical sociology.

The history of sociology in Austria and in Vienna points to diverse and competitive currents, differing in theoretical and epistemological starting points, research agendas and editorial resources. Particularly irreconcilable was the contrast between empirical sociology and social philosophy. This opposition did not correspond with the two institutionalized currents of the academic field, represented on one side by the legal, state and economic sciences of Lorenz von Stein, Eugen von Philippovich and Othmar Spann and, on the other side by the Faculty of Philosophy of Ludo Moritz Hartmann ${ }^{5}$ (1865-1924) and Wilhelm Jerusalem (1845-1923). As already shown, sociology at the universities was in general non-empirical, and its socio-philosophical outlook accompanied in many cases by a Catholic and sometimes even fascist-affinitive orientation (Spann and his circle), although there were some exceptions, such as the theoretically oriented Austro-Marxist Max Adler or Eugen von Philippovich with his interests in empirical social sciences, both already mentioned. However, the dominant strand at the University was anti-empirical. Its main proponent Othmar Spann, who began his career as a statistician, later distanced himself, radically and with antisemitic connotations, from empirical research (Spann called such research a useless effort to capture reality $\left.{ }^{6}\right)$.

The institutionalization of a scientific discipline is always mirrored in its methodological claims and aspirations, and this was also the case in Austrian sociology. However, the most important impetus for empirical sociology in its modern conception came not from University-grounded currents, but rather from the margins of the University environment, in which Charlotte Bühler (1893-1974) - as a woman and a Jew - was situated. She developed various innovative methods of empirical social research. In Austrian sociology, as in

5 Ludo Moritz Hartmann was a historian and social democratic politician.

6 "Der Geist der Zeit [...] kehrt sich von der öden Tatsachenjägerei ab" [Spann 1923]. 
the development and application of empirical research in general, women such as Käthe Leichter, Marie Jahoda, Else Frenkel-Brunswik, or Lotte Schenk-Danziger (1905-1992) played an essential role. This research developed under the influence of Austromarxism and from its very beginning was anti-provincial and linked to the international scene.

From the institutional point of view, it was non-university research funded by certain interested bodies (usually non-academic), which formally took the character of market research and public opinion polling, providing space not only for innovative approaches but reflecting the influence of Austromarxism, and leading, for example, to an orientation on issues of working-class education. This represents a marginal position - and with regard to the positioning of empirical sociologists, we can speak of multidimensional and intersectional marginalization [Kranebitter - Reinprecht 2018] as one of the essential constitutive elements of Viennese sociology. Its surprising vitality and innovative strength stemmed from such material and discursive marginal positions. It should be added that this marginal position changed over time and was overcome later in exile, where what had developed in Vienna as something marginal became - in the context of American sociology - a powerful and dominant perspective.

The topographic approach helps us to see more precisely this marginalization and associated persons, research teams, projects and text documents in the dimension of the real historical realm. Empirical sociology in Vienna was found almost entirely outside established institutions such as the University or the Academy of Sciences, where sociology was cultivated on the basis of provincially-oriented political and social sciences (Staats- und Gesellschaftswissenschaften), cut off from international debates. In such a structurally conservative academic environment, a huge part of people, interested in modern social sciences, were excluded: women who had no or very limited access to Universities or degrees; Jews who were confronted with strongly established antisemitism and German nationalist associations and fraternities; Marxists who found at the University a center of right-wing ideologies. However, this does not mean that the different sociologies of that time existed in parallel and were not connected. The viewpoint of localization grasps this situation as a social field, in which certain local conditions, research approaches, studies and the thoughts of sociologists are not perceived as isolated but as socially and spatially located.

\section{Empirical sociology and its marginal positions}

The positions of empirical sociology create a panorama of places and sites each connected with concrete practices in empirical research and the production of theoretical knowledge: private homes (salons) and research laboratories, coffee houses and centers for popular education, publishing and printing houses, party headquarters and labor organisations, residential buildings and factories, prisons and concentration camps. All of these places are multidimensional. They involve various practices, modes, persons, and situations and are relevant for the constitution of the discipline of sociology in multiple ways. However, it can be helpful to cluster these places and positions in order to make their role in the emerging field of sociology visible. What elements do all these places share?

A place always has a material component. The place can refer to a building, or an ensemble of buildings, streets, green areas etc. Behind the material aspect of a place is 
a plan after which its materiality was created. The materiality of a place is also important for its historicity. One can ask who used to live, work, stay in a place and - if the building still exists - who is using it at present. The material historicity of a place is also constituted by the physical traces of its past functions and purposes as well as other physical elements that tell one version of its story - like street signs and memorial plaques. The physical component of a place is also what is translated into a map or a city plan.

A place also refers to the people that were connected or involved with it. Inside a place, were it a residential home or an office, existed certain structures, hierarchies and/or power relations, which also often mirrored the social circumstances of a certain time. Thinking about the people frequenting a place necessarily leads to thinking about their practices and activities: the research designed, the knowledge generated, the data gained, the social experiments conducted. Places are also of biographical importance. Certain goals were achieved or fought for, some projects and ideas were oppressed, circumstances were changed; there were acts of resistance and certain individuals were marginalized because of their activities or features.

A place is also a position, where different social fields are meeting and overlapping each other: a position in the scientific field is often also a position within the political field. Different institutions, organizations, and policies are impacting a place, shape its dynamic, its status and discursive power, and relate it to other places and positions.

Having this in mind, taking a place as a starting point leads to other places, positions, areas, cities, but also people, ideas, texts, concepts, activities, groups, political actions and many more. What we find is not only a multidimensional structure of different modes and elements, where connections are just as important as positions. We also gain a collection of concrete material places that can be localized on a map and in many cases physically experienced until today. Methodologically, a core question asks about the access to these places, the documents, texts, studies, data which talk about and mention certain places.

For our purpose to demonstrate the relevance of a topographical approach for sociologizing the history of sociology, we are going to look closer at four examples, each referring to a type of place relevant for the constitution of sociology as a discipline in Vienna:

- Places of the production of knowledge,

- Places of the development and application of research methods,

- Places of the circulation and transmission of knowledge,

- Places of the realization of sociological concepts through interventions in society.

\section{Places of the production of knowledge}

Places and facilities where sociologists developed sociological and methodological approaches as well as important questioning and cooperated in various ways in order to develop innovative research can be considered places of the production of sociological knowledge. Concrete examples for places which provided the necessary space to generate sociological knowledge are, amongst others, private salons (e.g. the Vienna Society of Sociology, initiated by Rudolf Goldscheid) and Coffeehouses (relevant for intellectual circles), office rooms (e.g. Viennese Society- and Economy-Museum founded by Otto Neurath) and institutionalized places like University institutes (department for psychology) or the Chamber of Labor (Käthe Leichter). 
In the Austrian (and Viennese) history of sociology, one very important proponent for this type of place was the Wirtschaftspsychologische Forschungsstelle (Research Center for Economic Psychology) which was accommodated in Vienna's 1st district - in Wächtergasse 1 and Wallnerstraße 8 - in relative proximity to the Institute for Psychology of Vienna University which was headed by Karl and Charlotte Bühler and located outside the main University building (what we can take as a hint to the marginal position of the Bühlers in the University structures). Forschungsstelle and Psychology Department had various strong connections. They not only shared many of their employees, but also on a methodological level they referred and related to each other. A good example here is Charlotte Bühler's concept of Lebenslauf-Psychologie [Bühler 1933], which provided the theoretical framework for the works of a number of young researchers of the Forschungsstelle. One of them was the young Marie Jahoda, who wrote her dissertation by applying Bühler's approach to the biographies of people from the working class [Jahoda 2017 (1932)]. The local scientific research network also reached out to the Chamber of Labor (Arbeiterkammer), which did not only co-fund the famous Marienthal study ("sociography of an unemployed community"), but also through the cooperation between the leading figures of the Forschungsstelle and Käthe Leichter, who lead the women's department of the Chamber of Labor. Leichter, who had studied political science and economy at the University of Vienna and graduated in Heidelberg with a dissertation under the direction of Max Weber, was also a connection to the Frankfurt Institute for Social Research and especially to Carl Grünberg, one of the few Marxist scholars holding a professorship at the University of Vienna. On many other levels too, the Forschungsstelle was actively involved in the international social sciences. Its research approaches and methodological innovations were initially influenced by Anglo-American concepts [Zeisel 1988] and served themselves as an inspiration for the international social science research [Fleck 2007].

The Wirtschaftspsychologische Forschungsstelle developed its methods and practices both in scientific and market-oriented research. Its numerous commercial projects, such as the surveys for the bread factory Ankerbrot or the national radio broadcasting service RAVAG [Fleck 1990] were financial necessities and at the same time providing incentives for the development of modern research methodology, applying psychological knowledge and statistics. What is primarily recalled today, however, are its scientific research projects. Its most famous project was the research conducted in the municipality of Marienthal, after a striking majority of the community's inhabitants had become unemployed due to the shutdown of the textile factory, the main employer in Marienthal in the early 1930s [Jahoda - Lazarsfeld - Zeisl 1975 (1933)].

When Lazarsfeld won the Rockefeller Scholarship in 1933 and left for the United States, where he was forced to remain permanently, the leading position of the Forschungsstelle was taken over by Marie Jahoda ${ }^{7}$ and Gertrude Wagner. The number of researchers of the Forschungsstelle forced to go into exile in the context of Austrofascism and NS-regime, was considerable. During the fascist regime, the facilities of the Forschungsstelle also temporarily provided room for the underground work of the political resistance. Jahoda had to leave Austria in 1937 and found refuge in London. She later emigrated to New York

7 Marie Jahoda, later in exile, cooperated, among other things, in antisemitism research [Ackerman - Jahoda 1950]. 
where other members of the Forschungsstelle lived in exile, among them Hans Zeisel, ${ }^{8}$ Else Frenkel-Brunswik, and Paul Lazarsfeld. Jahoda later returned back to the UK where she pursued an academic career. For her and many other people of the Forschungsstelle, living in exile opened an opportunity to overcome the marginalized position and to move into more distinguished positions in the field of social sciences. For other people, the path led to the places of the Shoah. One of them was Käthe Leichter who was deported to the concentration camp Ravensbrück and murdered in Bernburg/Saale.

\section{Places of the circulation and transmission of knowledge transfer}

Many of the protagonists of Viennese sociology were involved in the area of popular education, driven by ideas of working-class emancipation. It was Otto Neurath's goal, for example, to communicate complex social, political and economic contents to people without access to education of all ages. Neurath, who was a leading figure of the Vienna Circle (Wiener Kreis) and very active in diverse areas of social and political life, developed together with a small team of people from different disciplines the Vienna method for pictorial statistics (Wiener Methode der Bildstatistik). This method was applied not only in publications but in accessible public spaces, especially in his Wiener Gesellschafts- und Wirtschaftsmuseum (Viennese Society and Economy Museum) whose exhibition rooms spread out in multiple parts of the city [Stadler 1982; Sandner 2014]. Other places of circulation of knowledge and knowledge transfer were still existing public universities (Volkshochschulen) aiming to provide lectures and courses in various areas for the working class. Many of their lecturers and teachers were social scientists, including also very famous personalities such as Hans Kelsen or Max Adler.

A traditionally relevant place of the circulation and transmission of knowledge are publishing houses. In the context of the emerging field of sociology, the "Anzengruber Verlag" played an important role. Founded by two brothers, Wilhelm and Philipp Suschitzky, the publishing house was located in a bookstore in Favoriten, a traditional working class and immigration district in Vienna. The case of this editing house is interesting for many reasons: It reflects the decentralized and peripheral position of sociological facilities in that period. The Suschitzky's were facing antisemitism and also strong obstructions through public authorities which tried to hinder them to open up a bookstore. The bookstore opened in 1901 and soon became a center of progressive and liberal intellectual circles. In 1904-1905 the publishing house was founded and published books, research reports, and brochures about various, often sociologically relevant topics. The Suschitzky's were closely related to the emancipatory ideas of social democracy, the pacifist and women's movement, and published manifests on social and sexual reforms. The list of published works by the Anzengruber Verlag shows the important role the publishing house played in distributing (often marginalized or even academically banned) sociological ideas and topics: Max Adler's publication on Georg Simmel (1919), Bruno Frei's housing study [Frei 1918], numerous texts by Rudolf Goldscheid, a brochure on education written by the young Paul Felix Lazarsfeld together with Ludwig Wagner (1924), a periodic paper and

8 Hans Zeisel worked as a statistician. Among his later works we can mention Say It with Figures, with an introduction by Paul F. Lazarsfeld [Zeisel 1947]. 
other publications by Jakob Levy Moreno, who is known today for sociometry, a method for measuring social relationships, theoretical and literary texts of liberal feminist thinker Rosa Mayreder as well as publications written by the social scientist Josef Popper-Lynkeus or the psychoanalyst Wilhelm Reich are just a few examples [Lechner 1994].

However, antisemitic and conservative hostilities against the two brothers and their small company became more and more threatening in the 1920s and were accompanied by economic struggles. Wilhelm Suschitzky committed suicide in 1934, his wife Adele took over his position. Philipp fled from Austria a few days after the Anschluss while his wife Olga continued to run the business with Adele. The publishing house was shut down by the authorities in 1938, addressed as a "Jewish-Marxist-pornographic" company. Philipp and Olga were arrested in France in September 1942 and most likely killed in Auschwitz [Lechner 1994].

\section{Places of the development and application of research methods}

Conducting a research project, gaining qualitative or quantitative data, applying methodological approaches, all depend on concrete, material places, and settings. These places can be factories, where the working and living circumstances of the laborers are being examined [Adler 1888] as well as the streets within certain areas, on which social journalistic texts will be written [Winter 1982], or residential buildings and areas. Housing was in the core of the research interest in early sociology: it was not only the focus of quantitative research and statistically founded studies [Philippovich 1894; Frei 1918, 1920] but was also addressed in many of the more journalistic texts (Sozialreportage) about the "social reality" of Vienna [Winter 1982]. Furthermore, the examination of housing situations was important in studies which tried to gain knowledge about the whole life situation of certain groups, e.g. the women of the working class [Leichter 1927, 1928, 1930, 1932], as well as in innovative research using methods of triangulation and the combination of quantitative and qualitative approaches, as it was the case in Marienthal, and also in theoretical texts about the analysis of individual happiness and needs [Neurath 1979 (1931)]. The various works, studies, and texts about the living and housing situations of especially poorer social groups rendered the residential buildings, working sites and places of sociability (e.g. pubs), visited by the researchers in order to gain data and information, into sociological places.

Especially the quantitative and descriptive studies of Eugen von Philippovich [1894] and Bruno Frei $[1918 ; 1920]$ focused on the living and housing conditions in the poor working class districts of Vienna with their overcrowded, dilapidated rental barracks and translated them into statistics in great detail. In many cases, the individual apartment buildings and their locations are described in a way that makes them easily identifiable within the city plan, and often their addresses were even published. Eugen von Philippovich was one of the first to visit 101 apartments in Vienna's districts Favoriten, Meidling, Ottakring, and Leopoldstadt in order to gain quantitative data. His brochure "Wiener Wohnungsverhältnisse" ("Viennese housing conditions") [Philippovich 1894] did not just present the results of his research but also gave space to his methodological thoughts about capturing the "realities" of housing in poor neighborhoods of Vienna. Bruno Frei applied similar methods. He was an intellectual who published books, journalistic articles and 
also more documentary works such as two brochures in which he presented the results of his housing studies, both conducted in very poor neighborhoods in Vienna. In 1918, his study "Wiener Wohnungselend" ("Viennese housing misery") was published in the Anzengruber Verlag. Two years later the brochure "Jüdisches Elend in Wien" ("Jewish misery in Vienna") came out, in which he tried to oppose the strong antisemitic biases that were dominating the society of Vienna by showing the extreme poverty that so many Jewish people, especially in the 2nd and 20th district, had to face and live in. Before presenting the results of his quantitative research, for which he and his team visited 222 apartments and other housing facilities, Frei counters the many absurd antisemitic prejudices and lies with rational yet passionately articulated arguments. Bruno Frei’s "Jüdisches Elend in Wien" takes a next step by publishing so-called Elendsphotographien (photographs of misery) of many of the described buildings, apartments, situations and the people living there. As the social documentary approach in general, also Frei's writings are driven by a political mission fighting the unjust and exploitative situation of the "poor" and "miserable" in capitalist society [Schwarz et al. 2007].

\section{Places of the realization of sociological concepts through interventions in society}

For many social scientists of that time sociological research did not only consist of pure research and theory but also implied a translation of findings into practice. To improve societal stability and to achieve justice and equality, to change the living and working conditions of the masses, and to secure certain living standards and welfare were goals anchored in the self-understanding of the social sciences in general. This has been particularly the case in Austria where sociology, as above mentioned, was characterized by a tension between approaches interested in problems of social order and top-down solutions on the one hand, and (more bottom-up oriented) approaches emphasizing the emancipatory potential of a modernized, industrialized society on the other. Places of the realization of sociological concepts are those where interventions in society took place.

In the early 19th century, settlements represented a characteristic place of this type. In its early period, the settlement movement in Vienna represented an autonomous and informal constellation of people from popular classes engaged in self-constructing their homes. At its beginning consisting of unregulated and "wild" construction activities, the movement came to be increasingly organized and also incorporated in the social democratic administration of the city after 1918. In the process of organizing and regulating the settlements and the people involved, sociological concepts came into play. A key role in developing and applying such concepts was taken by Otto Neurath. Neurath, who besides his involvement in the Vienna Circle and in the development of the Vienna methods of pictorial statistics also worked on issues of city planning and urban development [Sandner 2014], spotted potential in the informal settlements that were dwelling in the outskirts of Vienna since before the First World War. Their inhabitants did not only build simple houses with everything they could use, but also agricultural gardens, as the city was confronted with a food and nutrition crisis that forced many people to develop subsidiary strategies. For Neurath these settlements not only represented places of survival but also places of social experiment, strengthening community life and forms of local and basic solidarity. Neurath managed to centralize the organization of the individual settlements and became 
head secretary of the Austrian Verband für Siedlungs- und Kleingartenwesen (Association for housing and small gardens) [Hochhäusl 2011]. In his writings, he introduced new organizational and societal concepts aiming for the highest possible functionality by applying industrial and technological ways of production and combining centralizing top-down with empowering bottom-up strategies (e.g. [Neurath 1917]). Architectural uniformity, high functionality and a combination of centralization and empowerment are amongst the key characteristics of the settlement movement of Vienna for which Otto Neurath rendered the idea of Gemeinwirtschaft. This concept consisted of three main components: the principles of shared possessions and shared infrastructure within the settlements as well as a certain amount of unpaid work hours the future settlers had to contribute while building the settlements [Hochhäusl 2011].

Places of the realization of sociological concepts through interventions in society are of course the many, in some cases still existing, settlement buildings, but also places such as the Town hall of Vienna where, in 1923, a big exhibition took place, curated by Otto Neurath and leading into the foundation of his Museum für Siedlungs- und Städtebau which would later turn into the Wiener Gesellschafts- und Wirtschaftsmuseum [Wahl 2010].

\section{In conclusion}

In this article, we have presented an alternative way of looking at the history of Austrian, especially Viennese sociology around 1900 and in the first decades of the 20th century. Contrary to a traditional narration which shows how the discipline from its initial state gradually differentiated into a series of thought streams and directions, the topographic method proposed in this article is driven by the interest to incorporate also physical and material dimensions of a scientific field. This allows to counter the still dominant, although often rather implicit, linearity in telling the story of discipline by making visible the constellations of places and positions that constitute sociology as a field of conflict and struggles for hegemony. From a conceptual perspective, we prefer to use notions of place, localization and position instead of figuration or network in order to maintain the centrality of the materiality. The article demonstrated this perspective by introducing four typical places, each contributing to the constitution of the discipline in its own way. Based on a short depiction of the polyphonic and complex scenery of the sociological field, the article not only shows how the topographic approach may contribute to complement, modify and reformulate the standard interpretation of the history of Austrian sociology. The topographic approach opens up the possibility to discover new dimensions of this conflictual field, including mechanisms of intersectional marginalization which can be identified as a core and long-lasting element of the sociological landscape. One of the most important findings to which the use of the topographical approach contributes, concerns the fact that the multidimensional and intersectional (intersecting and intensifying as it concerned dimensions of gender, ethnicity, and class) marginalization created, at the same time, new axes of research interests and accelerated the emergence of a nationally and locally not bounded empirical sociology. Constituents allowing these dynamics include the decentral, multi-sited and trans-national character of places of knowledge production in consequence of the exclusion of its proponents from the Universities; the (economic) necessity and (political) willingness to develop research also by crossing disciplinary and 
sectoral borders; or the capacity to open the field of social sciences to until then marginalized and excluded groups. Austria was a good ground for scientific innovation but not for its institutionalization. This particularly refers to the field of empirical sociology. Its professionalization and international mainstreaming are immanently linked with the experience of marginalization and exile of its representatives.

\section{Bibliography}

Ackerman, Nathan W. - Jahoda, Marie [1950]. Anti-semitism and emotional disorder. A psychoanalytic interpretation. New York: Harper \& Bros.

Adler, Viktor [1888]. Die Lage der Ziegelarbeiter. In. Gleichheit 48.

Bourdieu, Pierre [1993]. Für eine Soziologie der Soziologie. In. Bourdieu, Pierre. Soziologische Fragen. Frankfurt am Main: Suhrkamp, pp. 77-82.

Bühler, Charlotte [1933]. Der menschliche Lebenslauf als psychologisches Problem. Leipzig: S. Hirzel.

Dayé, Christian - Moebius, Stephan (eds.) [2015]. Soziologiegeschichte. Wege und Ziele. Berlin: Suhrkamp.

Fleck, Christian [1990]. Rund um "Marienthal": von den Anfängen der Soziologie in Österreich bis zu ihrer Vertreibung. Vienna: Verlag für Gesellschaftskritik.

Fleck, Christian [1995]. Zum intellektuellen Umfeld der Wiener Jahre von Alfred Schütz. In. Leube, Kurt R. - Pribersky, Andreas (eds.). Krise und Exodus. Österreichische Sozialwissenschaften in Mitteleuropa. Vienna: WUV, Universitätsverlag, pp. 98-116.

Fleck, Christian [1999]. Für eine soziologische Geschichte der Soziologie. Österreichische Zeitschrift für Soziologie 24 (2): 52-65.

Fleck, Christian [2007]. Transatlantische Bereicherungen. Zur Erfindung der empirischen Sozialforschung. Frankfurt am Main: Suhrkamp.

Fleck, Christian [2015]. Skizze einer Methodologie der Geschichte der Soziologie. In. Dayé, Christian Moebius, Stephan (eds.). Soziologiegeschichte. Wege und Ziele. Berlin: Suhrkamp, pp. 34-111.

Frei, Bruno [1918]. Wiener Wohnungselend. Vienna: Anzengruber Verlag.

Frei, Bruno [1920]. Jüdisches Elend in Wien. Vienna - Berlin: R. Löwit.

Gumplowicz, Ludwig [1883]. Der Rassenkampf: Soziologische Untersuchungen. Innsbruck: Wagner.

Hochhäusl, Sophie [2011]. Otto Neurath - City Planning. Proposing a Sociopolitical Map for Modern Urbanism. Innsbruck: University Press.

Jacob, Christian [2007]. Lieux de savoir: Espaces et Communautés. Paris: Albin Michel.

Jahoda, Marie [2017 (1932)]. Lebensgeschichtliche Protokolle der arbeitenden Klassen. Dissertation. Studienverlag.

Jahoda, Marie - Lazarsfeld, Paul F. - Zeisel, Hans [1975 (1933)]. Die Arbeitslosen voMarienthal. Ein soziographischer Versuch über die Wirkungen langandauernder Arbeitslosigkeit. Frankfurt am Main: Suhrkamp.

Kranebitter, Andreas - Reinprecht, Christoph [2018]. Marxism Underground: Latent Marxism in Austrian empirical sociology. (Editorial). Österreichische Zeitschrift für Soziologie 43 (3): 219-224.

Langer, Josef (ed.) [1988]. Geschichte der österreichischen Soziologie. Konstituierung, Entwicklung und europäische Bezüge. Vienna: Verlag für Gesellschaftskritik.

Lechner, Annette [1994]. Die Wiener Verlagsbuchhandlung “Anzengruber-Verlag, Brüder Suschitzky" (19011938) im Spiegel der Zeit. Unpublished work. Vienna.

Leichter, Käthe [1927]. Frauenarbeit und Arbeiterinnenschutz in Österreich. Vienna: Verl. Arbeit und Wirtschaft.

Leichter, Käthe [1928]. Wie leben die Wiener Heimarbeiter? Eine Erhebung über die Arbeits- und Lebensverhältnisse von tausend Wiener Heimarbeitern. Vienna: Verl. Arbeit und Wirtschaft.

Leichter, Käthe (ed.) [1930]. Handbuch der Frauenarbeit in Österreich. Vienna: Kammer für Arbeiter und Angestellte in Wien.

Leichter, Käthe [1932] So leben wir ... 1320 Industriearbeiterinnen berichten über ihr Leben. Vienna: Verl. Arbeit und Wirtschaft. 
Masaryk Garrigue, Thomas [1881]. Der Selbstmord als soziale Massenerscheinung der modernen Zivilisation. Vienna: Carl Konegen.

Müller, Karl H. [1988]. Die Hochzeit der Sozialwissenschaften 1871-1938. In. Langer, Josef (ed.). Geschichte der österreichischen Soziologie. Konstituierung, Entwicklung und europäische Bezüge. Vienna: Verlag für Gesellschaftskritik, pp. 51-69.

Negt, Kluge [1972]. Öffentlichkeit und Erfahrung. Frankfurt am Main: Suhrkamp.

Neurath, Otto [1917]. Das umgekehrte Taylorsystem. Auch etwas zur Auslese der Tüchtigen. Deutscher Wille: des Kunstwarts 31: 19-25.

Neurath, Otto [1979 (1931)]. Wissenschaftliche Weltauffassung, Sozialismus und Logischer Empirismus. Ed. Rainer Hegselmann. Frankfurt am Main: Suhrkamp.

Norden, Gilbert - Reinprecht, Christoph - Froschauer, Ulrike [2015]. Frühe Reife, späte Etablierung: Zur diskontinuierlichen Institutionalisierung der Soziologie an der Alma Mater Rudolphina Vindobonensis. In: Fröschl, Karl Anton - Müller, Gerd B. - Olechowski, Thomas - Schmidt-Lauber, Brigitta (eds.). Reflexive Innenansichten aus der Universität. Disziplinengeschichten zwischen Wissenschaft, Gesellschaft und Politik. Göttingen: V\&R unipress - Vienna university Press, pp. 165-178.

Philippovich, Eugen von [1894]. Wiener Wohnungsverhältnisse. Berlin: Carl Heymanns Verlag.

Ratzenhofer, Gustav [1907]. Soziologie: Positive Lehre von den menschlichen Wechselbeziehungen. Leipzig: F. A. Brockhaus.

Sandner, Günther [2014]. Otto Neurath. Eine politische Biographie. Vienna: Zsolnay.

Schäffle, Albert [1875-1878]. Bau und Leben des sozialen Körpers. Vols. 1-4. Tübingen: Laupp.

Schwarz, Werner Michael - Szeless, Margarethe - Wögenstein, Lisa [2007]. Bilder des Elends in der Großstadt (1830-1930). In: Schwarz, Werner Michael - Szeless, Margarete -Wögenstein, Lisa (eds.). Ganz unten. Die Entdeckung des Elends - Wien, Berlin, London, Paris, New York. Katalog zur 338. Sonderausstellung des Wien Museums. Vienna: Christian Brandstätter Verlag, pp. 9-17.

Shils, Edward [1970]. Tradition, Ecology, and Institution in the History of Sociology. Daedalus 99 (4): $760-825$.

Spann, Othmar [1923]. Gesellschaftslehre. 2nd ed. Leipzig.

Stadler, Friedrich (ed.) [1982]. Arbeiterbildung in der Zwischenkriegszeit. Otto Neurath - Gerd Arntz. Ausstellungssaal der Wiener Arbeiterkammer, Wien, 26. April bis 23. Juni 1982. Österreichisches Gesellschafts- und Wirtschaftsmuseum. Vienna [u.a.]: Löcker.

Stein, Lorenz von [1856]. System der Staatswissenschaft. Vol. 1-2. Stuttgart: Cotta.

Torrance, John [1976]. The emergence of sociology in Austria, 1885-1935. European Journal of Sociology 17: $185-219$.

Wahl, Niko [2010]. Information als Allgemeingut. Otto Neurath und die Wiener Methode der visuellen Kommunikation. In. Kos, Wolfgang (ed.). Kampf um die Stadt. Politik, Kunst und Alltag um 1930. Katalog zur 361. Sonderausstellung des Wien Museums. Vienna: Czernin, pp. 177-183.

Winter, Max [1982]. Das schwarze Wienerherz. Sozialreportagen aus dem frühen 20. Jahrhundert. Ed. Helmut Strutzmann. Vienna: Österreichischer Bundesverlag.

Zeisel, Hans [1947]. Say It with Figures. (with an introduction by Paul F. Lazarsfeld). New York: Harper \& Row.

Zeisel, Hans [1988]. Die Wiener Schule der Motivforschung. In: Langer, Josef (ed.). Geschichte der österreichischen Soziologie. Konstituierung, Entwicklung und europäische Bezüge. Vienna: Verlag für Gesellschaftskritik, pp. 157-166.

Christoph Reinprecht is professor of sociology at the University of Vienna where he also heads the postgraduate master's programme in European Studies; he is also associated researcher at the Centre de la Recherche sur l'Habitat in Paris. His research interests include issues of migration and urban social dynamics, the analysis of social inequalities, and political sociology; a current research focus lies on the history of empirical sociology in Austria. 
Nora Walch works at the Institute for Sociology in Vienna, where she is doing research on the constitution of the social field of sociology in Vienna and its multiple positionings within the city.

Jiři Šubrt founded in 2009 and has since been leader of the Department of Historical Sociology at the Faculty of Humanities of Charles University. Over the longer term he has also given attention to the issues of time and memory. He is the author and editor of several books published in the Czech, English and Russian languages. One of his latest books was published under the title The Perspective of Historical Sociology in 2017 in the UK. 